\title{
Suggestion to Create a New Foraminiferal System
}

\author{
V. M. Podobina \\ Tomsk State University, Tomsk, Russia \\ Email: podobina@ggf.tsu.ru
}

How to cite this paper: Podobina, V.M. (2017) Suggestion to Create a New Foraminiferal System. Open Journal of Geology, 7, 577-587.

https://doi.org/10.4236/ojg.2017.74039

Received: February 3, 2017

Accepted: April 27, 2017

Published: April 30, 2017

Copyright $\odot 2017$ by author and Scientific Research Publishing Inc. This work is licensed under the Creative Commons Attribution International License (CC BY 4.0).

http://creativecommons.org/licenses/by/4.0/

\section{(c) (i) Open Access}

\begin{abstract}
The paper discusses a new conception of the foraminiferal system, which constitutes an extensive but rapidly developing group of organisms. In the author's view, this system is based on five criteria those of morphological, ontophylogenetic, geochronological, paleogeographical, and paleobiogeo-graphical ones. The morphological criterion is a cardinal one with regard to the chemical composition and microstructure of test walls. The rank of the established 15 subclasses of foraminifera is assigned to the class Foraminifera d'Orbigny, 1826. Thus, the scientists generalized the data on the foraminiferal studies and raised this group of organisms from a rank to a class in comparison with orders in the system known from "Basics of Paleontology" [1]. The phylogeny of separate subclasses established on the basis of five foraminifera development stages is of great importance because it corresponds to the morphological structure and crucial tectonic movements during the Phanerozoic. The studies of the morphological peculiarities of the foraminiferal tests are based on the various methods elaborated mainly by the author.
\end{abstract}

\section{Keywords}

Foraminifera, System, 5 Stages, Phylogeny

\section{Introduction}

The foraminiferal research has been done since the early XIX $^{\text {th }}$ century. The most intensive studies of these organisms were made in the $\mathrm{XX}^{\text {th }}$ century, but since the beginning of the $\mathrm{XXI}^{\text {st }}$ century a number of works devoted to this theme have significantly decreased.

The first investigations began in Western Europe in the $20^{\text {th }}$ of the XIX ${ }^{\text {th }}$ century. Those were the generalized works done by A. d'Orbigny (1826), A. Reuss (1862), Brady (1884), Cushman (1928), Sigal (1952) and others.

J. Cushman (the USA) is regarded as the creator of the first foraminiferal sys- 
tem, and many other American researchers worked in this direction. For example, big reports on these organisms made by A. Loeblich and E. Tappan (1964, 1987/88) are known.

In 1930-1940 the foraminiferal research started in the Soviet Union and it was associated with the oil areas of Baku. In 1940s the works written by D.M. Rauzer-Chernousova and A.V. Fursenko came out. The first national reference book called "Basics of Paleontology" [1] was created under the supervision of these outstanding scientists. The book presented the first system of the foraminiferal subclass with the subdominant orders and some other taxa.

On the basis of foraminiferal cytoplasm studies A.V. Fursenko determined their position in the rank relating to the subclass of the Protozoon Sarcodina type. In the subclass of foraminifera ("Basics of Palaeontology" [1] A.V. Fursenko established 13 orders with the subdominant taxa (superfamilies, families, subfamilies and genera). American scientists [2] [3] have established of Foraminiferal System, correspond to order (higher takson).

Further the improved foraminiferal system came out [4] [5]. In this system, N.I. Maslakova took into account the previous research done under the supervision of the scientists D.M. Rauzer-Chernousova, A.V. Fursenko ("Basics of Paleontology" [1], V.I. Mikhalevich [6] [7] [8], Kh.M. Saidova [9]. The works written by A. Loeblich and H. Tappan [10], M.A. Kaminski [11] [12] have been singled out by the author. These scientists generalized the data on the foraminiferal cytoplasm studies and raised this group of organisms from a rank to a class.

The author of the present paper has studied the fossil foraminifera for many years [13]-[25] and took part in creation of Foraminiferal System. Also, author supports the investigations of N.I. Maslakova and the other scientists who published significantly improved systems. But the author has increased the number of subclasses (instead 8 now 15) and added many may orders which were earlier included in the rank of superfamilies or families in [1].

The creation of foraminiferal system is also based on the researches done by the author during more 50 years and take into account of investigations abovementioned scientists.

Thus, with reference to the author, the Foraminifera d'Orbigny class 1826 unifies 15 subclasses. It immediately follows that eight subclasses were established by V.I. Mikhalevich, N.I. Maslakova, M.A. Kaminski. In our opinion, Textulariata Mikhalevich, 1980 subclass turned out to be combined because it does not comply with the established taxonomic criteria. As a result of it, this subclass has been removed by author. Instead of Textulariata by Michalevich, 1980 the author distinguished six subclasses: Astrorhiziata, Ammodisciata, Rzehakiniata, Textulariata (the taxon of just the same name but it unifies subdominant orders). Also author added the following subclasses: Ataxo-phragmiata, Orbitolinata, Buliminata, Nummulitiata. Two last subclasses were distinguished by the author from the Rotaliata subclass. In doing so, the author of this paper has added eight subclasses to the earlier known 8 ones [24] [25].

The distinction of all subclasses is based on the peculiarities of the chemical 
composition of the wall and the morphological structure of shells. Ontophylogenetic, geochronological, paleogeographical and paleobiogeo-graphical criteria are also taken into account [16] [20]. In during Fanerozoic author has been establiched 5 stages of Foraminiferal Phylogeny, which correspond to end of tectonic epoches. These stages were base to add 8 new subclasses except known earlier (also 8 subclasses). The new order Haplophragmiida Podobina, 2014 isolated from Lituolidae according to their chemical composition, microstructure of the wall (agglutinated quartz-siliceous) and the morphological structure of shells are assigned as the separate orders in the Ammodisciata Podobina, 2014. As this takes place, except morphological peculiarities of shells as well as the abovementioned criteria are also taken into consideration.

In A.V. Fursenko's [26] and V. Podobina's [16] [20] [21] [24] [25] opinions, it is not necessary to proceed from only one morphological criterion in order to solve the problems of foraminiferal systematics. It is necessary that we should take into consideration the total combination of all the above-mentioned five criteria.

The recently published work [27] presents a new foraminiferal classification based on the molecular research which results in determining two subclasses and one complex. Unfortunately, in our opinion, this technique is not progressive because such big orders as Lagenida, Fusulinida and Involutinida came to the "incertae sedis" group.

\section{Results of the Investigation}

The author of the present paper has suggested a foraminiferal system in the rank of the class d'Orbigny, 1826, including 15 subclasses, 13 of which were known in the rank of the order in the system from "Basics of Paleontology" [1]. In its further development of the system of these organisms A.V. Fursenko [26] recommended the national researchers to use this basic standard reference book. These recommendations served as a basis for the suggested system of the foraminifera class where the well-known subdominant orders, rarely subfamilies, families were raised in the rank by the Podobina [24] [25] up to fifteen subclasses and 11 orders added. In doing so, the author of the paper used four above-mentioned criteria along with the morphological one in the foraminiferal systematics.

The author of the paper concerned has been studying the fossil foraminifera [13]-[25], supports and adds the research done by N. I. Maslakova [4] [5] dealing with a significantly specified system. As it was mentioned earlier, such a subclass, however, which is called Textulariata Mikhalevich, 1980, presented in the system of N. I. Maslakova and the classification of agglutinated foraminifera [11] [12] includes heterogeneous orders which on the basis of their chemical composition, microstructure of the wall, and some other criteria (ontophylogenetic, geochronological, paleogeographical, paleobiogeographical) can constitute independent subclasses. In the author's view, these taxa, or new subclasses by any definition correlate partly with the orders which had been earlier suggested under the supervision of D. M. Rauzer-Chernousova and A. V. Fursenko ("Basics 
of Paleontology" [1] and A.V. Fursenko [26]). As previously noted, the author of the present paper increased the number of the subclasses (to 15) and orders to 11 which had been earlier known in the foraminiferal surveys of the superfamilies and families rank [1] [24] [25].

The proposed system of foraminifera is based on the research done by the author and the above-mentioned scientists.

V.M. Podobina's monograph [25] with 47 foraminiferal plases presents a brief description of all subclasses and orders distinguished by the author and the other researchers. The descriptions of taxa are accompanied by concise information about the morphology of shells, composition and microstructure of a wall, stratigraphic interval of their development, facial assignment and connection with definite paleobiogeographical subdivisions.

As an example, the paper provides the paleontological plates (1 and 2) from

Foraminiferal system (higher taxa)

Zoa Kingdom. Animals

Subkingdom Protozoa Goldfuss, 1818

Protozoan organisms

Phylum Sarcodina Dujardin, 1838. Sarcodina

Class Foraminifera d'Orbigny, 1826

Foraminifera

1. Subclass Allogromiata Fursenko, 1958

Order Allogromiida Furssenko, 1958

2. Subclass Astrorhiziata Podobina, 2014

Order Astrorhizida Lankester, 1885

Order Saccamminida Podobina, 2015

Order Reophacida Podobina, 2014

3. Subclass Ammodisciata Podobina, 2014

Order Ammodiscida Fursenko, 1958

Order Haplophragmiida Podobina, 2014

Order Lituolida Podobina, 2014

4. Subclass Lagenata Maslakova, 1990

Order Lagenida Lankester, 1885

Order Polymorphinida Wedekind, 1937

5. Subclass Textulariata Podobina, 2014

Order Palaeotextulariida Hohenegger et Piller, 1975

Order Textulariida Lankester, 1885

6. Subclass Ataxophragmiata Podobina, 2014

Order Trochamminida Podobina, 2014

Order Ataxophragmiida Schwager, 1877

7. Subclass Orbitolinata Podobina, 2014

Order Orbitolinida Maslakova, 1990

Order Tetrataxida Podobina, 2014

8. Subclass Fusulinata Maslakova, 1990

Order Parathuramminida Mikhalevich, 1980
Order Moravamminida Maslakova, 1990

Order Nodosinellida Maslakova, 1990

Order Endothyrida Furssenko, 1958

Order Fusulinida Wedekind, 1937

Order Involutinida Hohenegger et Piller, 1975

\section{Subclass Miliolata Saidova, 1981}

Order Cornuspirida Jirovec, 1953

Order Miliolida Delage et Heronard, 1896

Order Soritida Saidova, 1981

Order Alveolinida Mikhalevich, 1980

10. Subclass Rzehakiniata Podobina, 2014

Order Silicinida Podobina, 2014

Order Rzehakinida Saidova, 1971

11. Subclass Rotaliata Mikhalevich, 1980

Order Rotaliida Lankester, 1885

Order Nonionida Podobina, 2014

Order Elphidiida Podobina, 2014

12. Subclass Globigerinata Maslakova, 1990

Order Globigerinida Lankester, 1885

Order Heterohelicida Fursenko, 1958

13. Subclass Buliminata Podobina, 2014

Order Buliminida Fursenko, 1958

Order Bolivinitida Podobina, 2015

Order Pleurostomellida Podobina, 2014

Order Cassidullinida Voloshinova, 1970

14. Subclass Spirillinata Maslakova, 1990

Order Spirillinida Hohenegger et Piller, 1975

15. Subclass Nummulitiata Podobina, 2014

Order Orbitoidida Baschkirov et Antonischin, 1974

Order Nummulitida Lankester, 1885 
V. M. Podobina's monography [25] and the descriptions of the Haplophragmiida and Lituolida orders of the Ammodisciata Podobina, 2015 subclass (at the end of the chapter 2).

A. V. Fursenko [26] suggested developing and improving the foraminiferal system established in "Basics of Paleontology" [1] consisting of thirteen orders of the Foraminifera subclass. In connection with the raising of the foraminiferal rank to the class [4] [5] [10] [11] [24] [25], V. M. Podobina considers almost all thirteen orders of the national reference book as separate subclasses. In addition, two new subclasses-Orbitolinata Podobina, 2014 and Rzehakiniata au view, on the peculiarities of the chemical composition of a wall and the morphological structure of shells. Besides, the ontophylogenetic, geochronological, paleogeographical and paleobiogeographical criteria are also taken in to account. According to the chemical composition, the wall microstructure (agglutinated, quartz-siliceous) and the morphological structure of shells, the new order Haplophragmiida Podobina, 2014 was distinguished from the Lituolida and assigned to the Ammodisciata, Podobina, 2014 subclass. As this take place, the other morphological peculiarities of shells as well as their above-mentioned criteria [16] [18] [19] [20] [21] [24] [25] are also taken into consideration.

The suggested specified foraminiferal system is much more related to the well-known system ("Basics of Paleontology") [1] which we usually use in everyday scientific and practical activities.

In the opinion of A. V. Fursenko [26] and V. M. Podobina [16] [20] [21] [24] [25] to solve the problems of foraminiferal systematic using the paleontological data there one cannot proceed from only one criterion, as a rule, a morphological one. It is necessary that we should take into consideration the total combination of all above-mentioned five criteria.

Recently a new foraminiferal classification has been worked out. It is based on the molecular research done [26]. Two new classes-those of Globothalamea and Tubothalamea Foraminifera in the phylum d'Orbigny, 1826 are also established.

One-chamber forms with organogenic and agglutinated wall are grouped into a Monothalamids complex. The Globothalamea class includes multi-chamber forms, the chambers of which are of a spherical form. In the Tubothalamea class one can single out multi-chamber forms which chambers are of a tubular form. In this system among the Monothalamids complex two one-chamber orders (Allogromida and Astrorhizida) are established. Several fairly abundant orders (Lagenida, Fusulinida and Involutinida) are regarded as "incertae sedis", that is the groups of the forms of unclear systematic position. The suggested system by the authors concerned has been created with regard to only one criterion (that of a morphological one) based on the data in terms of the molecular composition of the foraminifera. Therefore, this classification deserves further thorough investigations and then it will be possibly considered as one of the reliable systems.

For example auther of this paper show the description of two orders (Haplophragmiida Podobina, 2014 and Lituolida Podobina, 2014), which were estab- 
lished the first time [24] [25]. On two paleontological plates $(1,2)$ you may see characteristic genera and species of these orders.

Subclass Ammodisciata Podobina, 2014

Order Haplophragmiida Podobina, 2014

[nom. transl. Podobina, 2014 (ex Haplophragmoididae Maync, 1952)]

The shell is spiral-plane or streptoid, from involut to evolut. During the $2^{\mathrm{d}}$ stage of its development the shell is unfold and of a unilinear form; the shell opening is basal or septal, singular or multiple, final. The wall is simple, often having a pseudo-chitin lining, also agglutinated, and quartz-siliceous. They are distributed in terrigenic facies of the Boreal and Arctic circumpolar belts. At present to Carbon (Plate 1, images 1-9).

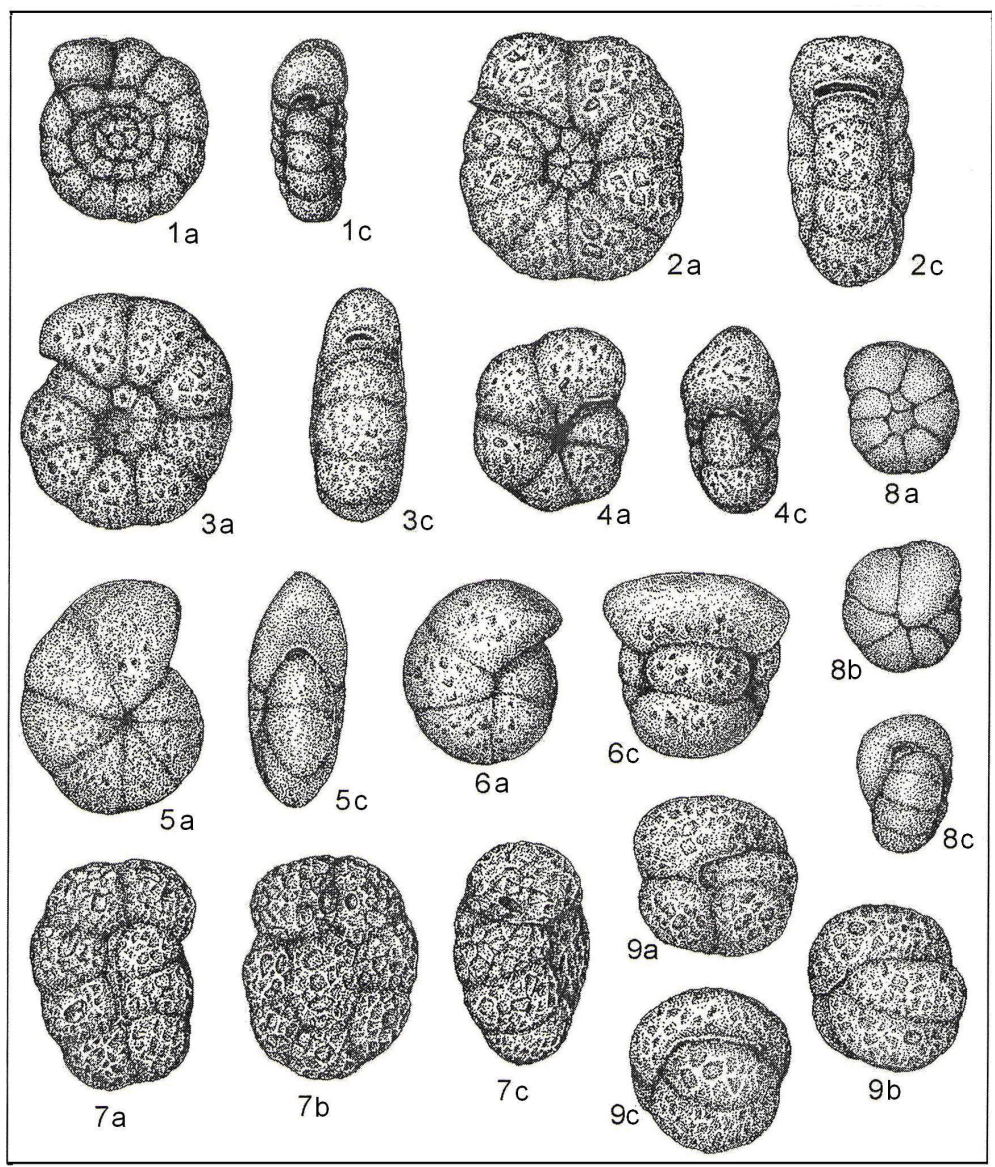

Explanation to Plate 1. 1a-1c. Trochamminoides proteus (Karrer). Typical specimen. Modern form; the Mexican Bay coast; 25 (Loeblich and Tappan, 1964). 2a-2c. Labrospira crassimargo (Norman). Holotype. Modern form; Swedish fiords; x 40 (Hoeglund, 1947). 3a-3c. Labrospira collyra (Nauss). No. 145. The Upper Cretareous (Turonian); Western Siberia, Omsk region, borehole 13-r, depth interval 10,100 - 10,010 m; 60 (Podobina, 1966). 4a-4c. Haplophragmoides canariensis (d'Orbigny). Lectotype No. 398. Modern form; the Atlantic Ocean near the Canary Islands; x 60 (Podobina, 1974). 5a-5c. Haplophragmoides rota Nauss sibiricus Zaspelova. No. 167. The Upeer Cretareous (Turonian); Western Siberia, Omsk region, Uyskian profile, borehole 20-k, depth 8800 m; x 60 (Podobina, 1966). 6a-6c. Cribrostomoides exploratus Podobina. Holotype No. 112. The Upper Cretareous (Santonian); Western Siberia, Tomsk region, Parabel-Chuzic profile, borehole 3-k, depth interval 40,895 39,715 m; x 80 (Podobina, 1966). 7a-7b-7c. Recurvoides contortus Earland. Typical species. Modern form; the Antarctic; $x 40$ (Loeblich and Tappan, 1964). 8a-8b-8c. Recurvoides magnificus Podobina. Holotype No. 110. The Upper Cretareous (Campanian); Western Siberia, Tomsk region, Ambarskaya area, borehole 1-r, depth interval 7180 - 7120 m; x 40 (Podobina, 1966). 9a-9b-9c. Adercotryma glomerata Brady. Typical species. Modern form; the Atlantic Ocean near Greenland island; x 80 (Loeblich and Tappan, 1964).

Plate 1. Typical genera and species of order Haplophragmiida Podobina, 2014. 
Order Lituolida Podobina, 2014

[nom. transl. Podobina, 2014 (ex Lituolidea Reuss, 1861)]

The shell is multi-chamber, spiral-plane or streptoid, involut. During the later stage it is of a unilinear form. Its shell opening is simple or complex, cribrose. The wall is calcareous with microgranular microstructure, sometimes it is pseudo-alveolar. They occur in carbonate or terrigenic facies having carbonate matter in the Boreal or Tethys ocean belts, Jura-Cretaceous Plate 2.

\section{Foraminiferal Phylogeny}

The author's work [25] and the present paper provide the results of the phylogenetic studies of the foraminiferal subclasses and envisage five stages in their development connected with the epochs of the tectogenesis.

Five major stages in the foraminiferal development are clearly distinguished in Figure 1.

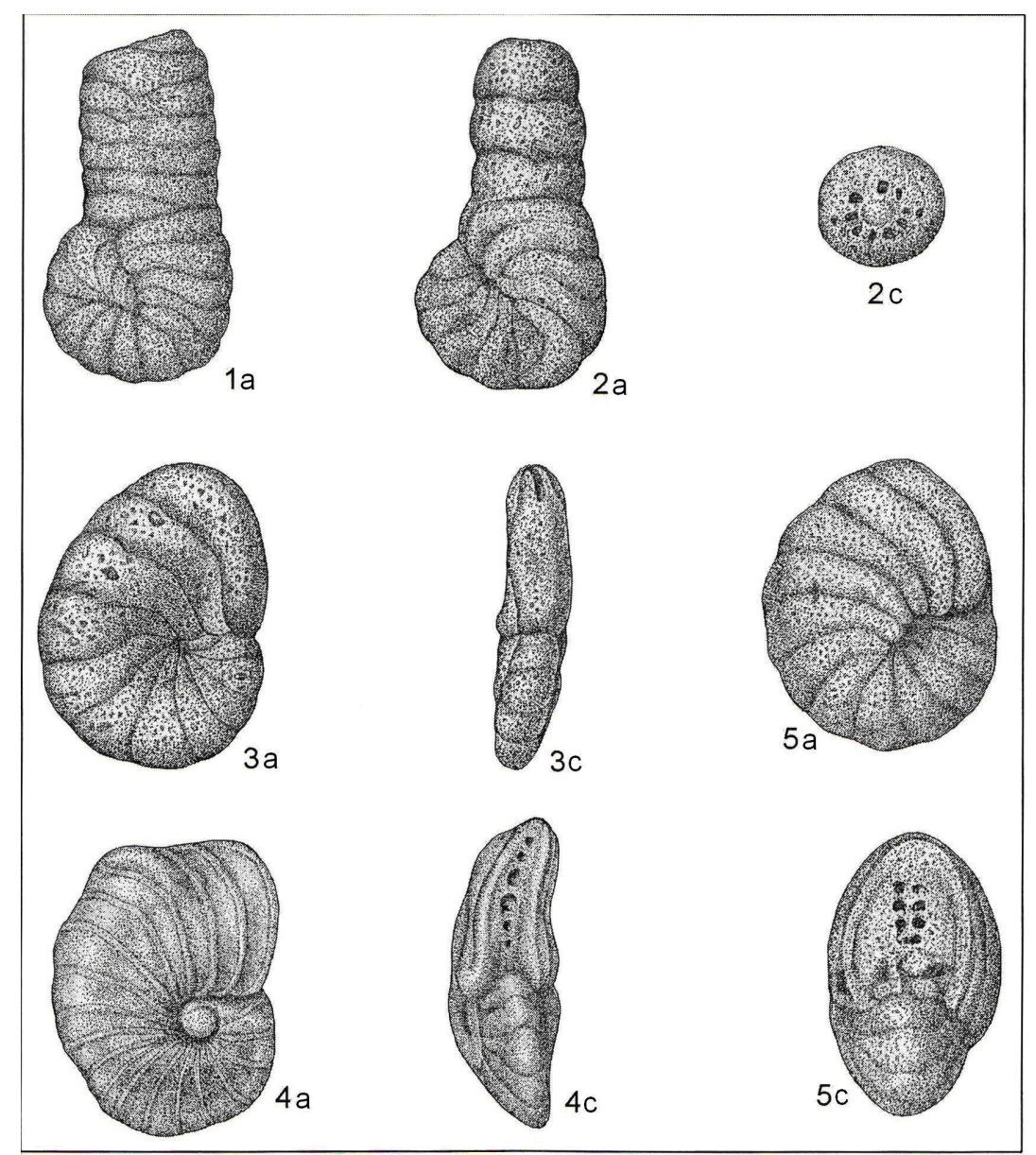

Explanation to Plate 2. 1a; 2a-2c. Lituola nautiloidea Lamarck. 1-No. 1a (in the TSU collection). The Upper Cretaceous (Campanian); received from France (Mendon formation), x 20 (Podobina, 1978). 2-Topotype (in the of Kanzas University, the USA). The Upper Cretaceous (Campanian); France (Mendon formation), x 20 (Loeblich and Tappan, 1964). 3a-3c. Phenacophragma assurgens Applin, Loeblich et Tappan. Holotype. The Lower Cretaceous (Albian); the USA (Texas); x 60 (Loeblich and Tappan, 1987/88). 4a-4c; 5a-5c. Stomastoecha plummerae Applin, Loeblich et Tappan. 4-Holotype. The Lower Cretaceous (Albian); the USA (Texas); x 40 (Loeblich and Tappan, 1964). 5-Paratype (in the Cushman laboratory collection, the USA). The Upper Cretaceous (Campanian); France (Mendon formation), x 20 (Loeblich and Tappan, 1964).

Plate 2. Typical genera and species of orders Lituolida Podobina, 2014. 


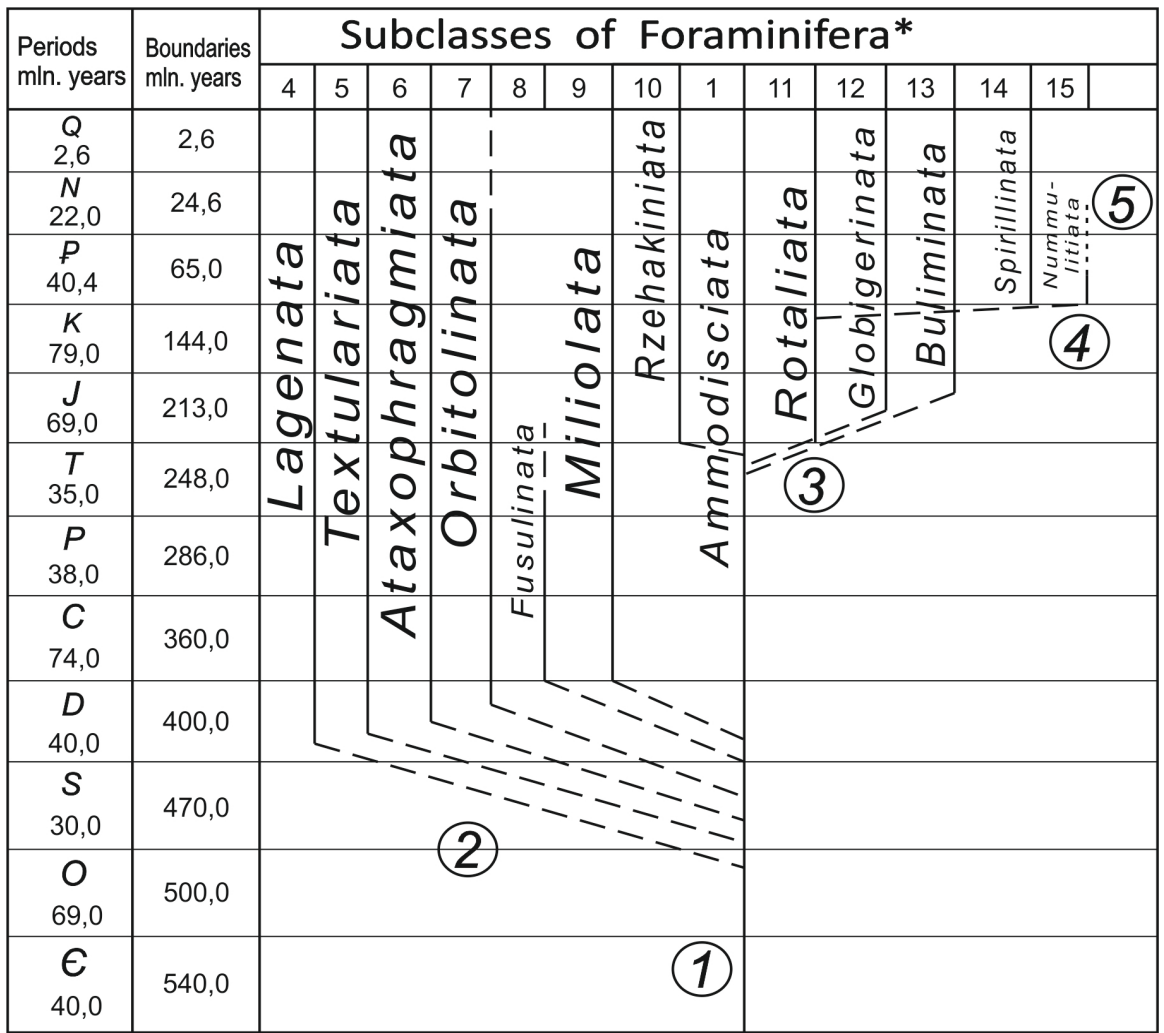

*Allogromiata and Astrorhiziata subclasses-emergence since the Late Docembrian and existence during the Phanerozoic. They give to rise to the Ammodisciata subclass: $1^{\text {st }}$ stage-emergence of these three subclasses and existence up to now. $2^{\text {d }}$ stage-emergence of 6 subclasses $(4-9)$ with $O$ and $\mathbf{S}$, the peak of their activity with $\mathrm{D} .3^{\mathrm{d}}$ stage-emergence of 4 subclasses $(10-13)$ with $\mathrm{T}$, the peak of their activity with $\mathrm{J}$ and $\mathrm{K} .4^{\text {th }}$ stage-emergence of 2 subclasses $(14 ; 53)$ in the Late $\mathrm{K}$, the peak of their activity in $\mathbf{P}$ (Eocene). $5^{\text {th }}$ stage-extinction of 2 subclasses $(7 ; 15)$ by the Late Eocene, emergence of new Globigerinidae taxa.

Figure 1. Scheme of foraminiferal class phylogeny.

It should be noted that not only extinction but emergence of new taxa of foraminifera are assigned to the geochronological boundary

The five established stages in the development of foraminifera mainly correspond to the completion of the epochs to the end of tectonic movements.

Establicshing 5 stages of Foraminiferal Phylogeny been have given opportunity to establish 15 subclassis, which have their range in development. Each stage correspond to end of the tectonic movement Epoch and accoding of shell development anther have defined the rank of subclassis. These stages of Foraminiferal development have helped to create more natural Foraminiferal System [24] [25].

\section{Conclusions}

The well-known system [25] of the higher taxa (subclasses, orders) of the class Foraminifera d'Orbigny, 1826 has been worked out on the basis of the national reference book "Basics of Paleontology" [1]. The rank of the foraminifera is raised to a class according to the recent research of the cytoplasm of these organisms [4] [5] [10] [11] [24] [25]. The rank of the orders distinguished in the reference book "Basics of Paleontology" [1] is viewed by the author as the sub- 
classes and several subdominant superfamilies and families are treated as orders. 15 subclasses in class Foraminifera are established by the author (including 8 subclasses, establishing by the other scientists. One of them Trochamminata is wrong and author has written about it).

The position of the subdominant taxa (superfamilies, families, subfamilies and genera) should be specified further on the basis of the research of the separate foraminiferal groups.

The author has succeeded in establishing three orders in the subclass Ammodisciata Podobina, 2014 relying on the investigation of the topotypes of separate genera which serve as the basis for distinguishing superfamilies, which rank is raised to orders [16] [24] [25]. In the author's opinion, such analogous superfamilies and later on possibly orders may be established in the subclass Ataxophragmiata Podobina, 2014, where the existence of twin genera [23] has already been repeatedly proved. They differ in their chemical composition, wall microstructure, morphological structure of shells along with some other known criteria.

In establishing the new subclasses the author sought to follow the system formed under the supervision of D.M. Rauzer-Chernousova and A.V. Fursenko [1] with the hope of further investigation which will be based on the national classification. The author has also used separate taxa, mainly genera from the well-known American system [2] [3].

Consequently, in the process of studies and correlation of the foraminifera using the well-established criteria, the suggested foraminiferal system will be improved. In doing so, it is necessary that we should take into account the data on the chemical composition, and wall microstructure. A complex of criteria with due regard for the morphological structure will provide an opportunity to establish much more natural and valuable foraminiferal system.

\section{Acknowledgements}

Many thanks to Prof. Zhihong Wang and Na Cheng (Joanna) for the help in publishing this paper.

\section{References}

[1] Basics of Palaeontology (1959) General Part. Protista. M.: Academy of Sciences of the USSR Press, 111-367. (In Russian)

[2] Loeblich, A.R. and Tappan, H. (1964) Sarcodina Chiefly "Thecamoebians" and Fopaminiferida: Treatise on Invertebrate Paleontology. Pt. C.: Protista. Lawtence: Univ. Kansas Press, Vol. 1-2, 900.

[3] Loeblich, A.R. and Tappan, H. (1987/88) Foraminiferal Genera and Their Classification. Van Nostrand Reinhold Company, New York, Vol. I. 970 p., Vol. II, 847 p.

[4] Maslakova, N.I. (1990) Criteria of Isolation of Higher Foraminiferal Taxa. In: Menner. V.V., Ed., Invertebrate Systematic and Phylogeny, M.: Science, 22-27. (In Russian)

[5] Maslakova, N.I. and Gorbachik, T.N. (1995) Systematic Part. Class of Foraminifera. Micropalaeontology: Textbook. M.: Moscow State University Press, 13-111. (In Ru- 
ssian)

[6] Mikhalevich, V.I. (1980) Systematics and Evolution of Foraminifera in the Light of New Data on Their Cytoplasm and Ultrastructure. Work of the Zoological Institute. L., Vol. 94, 42-61.

[7] Mikhalevich, V.I. (1998) Foraminiferal Macrosystem: The Academy of Sciences News. Biological Series, Part II, 266-271. (In Russian)

[8] Mikhalevich, V.I. (2000) Foraminifera d'Orbigny, 1826. Protista: Zoological Manual. Part I. Alimov, A., Ed., Science Press, 533-623.

[9] Saidova, Kh.M. (1981) About the Modern State of the System of Upspecific Taxa of the Cenozoic Benthonic Foraminifera. M.: The Academy of Sciences the USSR Press, 73 p. (In Russian)

[10] Loeblich, A.R. and Tappan, H. (1994) Foraminifera of the Sahul Shelf and Timor Sea. Cushman Foundation for Foraminiferal Research Special Publication, Vol. 31, 661.

[11] Kaminski, M.A. (2004) The Year 2000 Classification of the Agglutinated Foraminifera. Proceedings of the Sixth International Workshop on Agglutinated Foraminifera, Grzybowski Foundation, Special Publication, No. 8, 237-255.

[12] Kaminski, M.A. (2014) The Year 2010 Classification of the Agglutinated Foraminifera. Micropaleontology, 60, 89-107.

[13] Podobina, V.M. (1966) Foraminifera of the Upper Cretareous of the Western Siberian Plain. Nauka, Moscow, 148 p. (In Russian)

[14] Podobina, V.M. (1974) On the Issue of Classification and Phylogeny Some Cretareous and Palaegene Lituolida of Western Siberia. Issues of Micropaleontology. Nauka, Moscow, Issue 17, 5-21. (In Russian)

[15] Podobina, V.M. (1975) Foraminifera of the Upper Cretareous and the Palaegene of the West-Siberian Plain, Their Significance for Stratigraphy. Tomsk State University Press, Tomsk, 40. (In Russian)

[16] Podobina, V.M. (1978) Systematics and Phylogeny Haplofragmiida. Tomsk State University Press, 91 p. (In Russian)

[17] Podobina, V.M. (1989) Foraminifera and the Zonal Stratigraphy of the Upper Cretareous in Western Siberia. Tomsk State University Press, Tomsk, 175 p. (In Russian)

[18] Podobina, V.M. (1993) New Data on Composition and Microstructure of Agglutinated Foraminifer Wall. International Conference on Agglutinated Foraminifers, Krakow, 8-12 September 1993, 1 p.

[19] Podobina, V.M. (1995) Nodozariidae of the Late Cretaceous of Western Siberia. Tomsk State University Press, 203 p. (In Russian)

[20] Podobina, V.M. (1998) Foraminifera and biostratigraphy of the Palaeogene of Western Siberia. NTL Press, Tomsk, 338 p. (In Russian)

[21] Podobina, V.M. (2000) Foraminifera and Biostratigraphy of the Upper Cretaceous in Western Siberia. NTL Press, Tomsk, 388 p. (In Russian).

[22] Podobina, V.M. (2009) Foraminifera and Biostratigraphy of the Upper Cretaceous and Paleogene in Western Siberia. Tomsk State University Press, Tomsk, 432 p. (In Russian)

[23] Podobina, V.M. (2012) Twin Genera of Agglutinated Foraminifera in the Conditions of Their Dwelling (Based on the Ataxophragmiida Order): Modern Micropaleontology. Gelendzhik, 136-139. (Works of All-Russian Micropaleontological Session) (In Russian) 
[24] Podobina, V.M. (2014) Suggested System of Foraminifera (Higher Taxa). Tomsk State University News, No. 380, 215-224.

[25] Podobina, V.M. (2015) Foraminiferal System (Higher Taxa). Tomsk State University Press, Tomsk, 172 p. (In Russian)

[26] Fursenko, A.V. (1978) Introduction into Foraminiferal Studies. Science, Novosibirsk, 242 p. (Works of the IGiG of Siberian Branch of the Academy of Sciences USSR. Issue 391) (In Russian)

[27] Pawlowski, J., Holzmann, M. and Tuszka, J. (2013) New Supraordinal Classification of Foraminifera: Molecules Meet Morphology. Marine Micropaleontology, 100, 1 10. https://doi.org/10.1016/j.marmicro.2013.04.002

\section{Submit or recommend next manuscript to SCIRP and we will provide best} service for you:

Accepting pre-submission inquiries through Email, Facebook, LinkedIn, Twitter, etc. A wide selection of journals (inclusive of 9 subjects, more than 200 journals)

Providing 24-hour high-quality service

User-friendly online submission system

Fair and swift peer-review system

Efficient typesetting and proofreading procedure

Display of the result of downloads and visits, as well as the number of cited articles

Maximum dissemination of your research work

Submit your manuscript at: http://papersubmission.scirp.org/

Or contact ojg@scirp.org 